\title{
Production of vasoactive amines during the ripening of Pecorino Carmasciano cheese
}

\author{
R. Mercogliano • A. De Felice • C. Chirollo • \\ M. L. Cortesi
}

Published online: 18 May 2010

(C) Springer Science+Business Media B.V. 2010

\begin{abstract}
The aim of this study was to evaluate the production of the vasoactive amines, histamine and tyramine, and of other biogenic amines (putrescine, cadaverine, spermidine, and spermine) during the ripening of pecorino Carmasciano cheese, a traditional Italian cheese produced with raw sheep milk. Vasoactive amines, which may pose health risks for consumers, showed relatively low levels near the end of Carmasciano ripening $(136.41 \mathrm{mg} / \mathrm{kg}$ tyramine and $65.5 \mathrm{mg} / \mathrm{kg}$ histamine). The other biogenic amines were also detected and showed increasing levels with time. Results demonstrated that the concentrations of the vasoactive amines were always below the limits established for other foods. However, the data concerning raw materials and the increasing trend of certain biogenic amines highlight the need to control indigenous bacterial populations responsible for amine production, including the implementation of Good Manufacturing Practices and adequate training of staff.
\end{abstract}

Keywords Vasoactive amines $\cdot$ Pecorino Carmasciano cheese $\cdot$ Food safety

$\begin{array}{ll}\text { Abbreviations } \\ \text { BA } & \text { biogenic amines } \\ \text { TYR } & \text { tyramine } \\ \text { HIS } & \text { histamine } \\ \text { PTR } & \text { putrescine } \\ \text { CAD } & \text { cadaverine } \\ \text { SPR } & \text { spermine } \\ \text { SPD } & \text { spermidine } \\ \text { MAO } & \text { mono amine oxidase }\end{array}$

\section{Introduction}

Biogenic amines (BA) are organic bases of low molecular weight produced in food by bacterial free amino acid decarboxylases (Valsamaki and Michaelidou 2000). In cheeses BA

$\overline{\text { R. Mercogliano }(\bowtie) \cdot A . \text { De Felice }} \cdot$ C. Chirollo $\cdot$ M. L. Cortesi Dipartimento di Scienze Zootecniche e Ispezione degli Alimenti, Università degli Studi di Napoli Federico II, Via F. Delpino 1, 80137 Napoli, Italy e-mail: raffaella.mercogliano@unina.it 
formation is caused by curdling and cheese decarboxylase-positive microorganisms. Histamine (HIS), tyramine (TYR), putrescine (PTR), cadaverine (CAD), spermidine (SPD), spermine (SPR), tryptamine, and phenylethylamine are frequently found in these products. Cheese is a food commonly associated with vasoactive amines, second only to fish products. HYS and TIR show biological activity and may have toxic effects in sensible consumers. HIS causes "histamine poisoning," which is characterized by histaminergic crisis. TYR is responsible for "cheese syndrome," which is characterized by hypertension crisis and headaches (Stratton and Hutkins 1991).

Pecorino Carmasciano cheese is a traditional Italian cheese produced in a small village in High Irpinia (Avellino, Italy). Cheese making takes place in kitchens or cellars, using raw whole sheep milk from the evening and morning milkings. The milk is brought to $40-45^{\circ} \mathrm{C}$ for 15-20 min, curdled with lamb curdle, dry salted after $24 \mathrm{~h}$, and massaged with oil, wine, and wine vinegar every other day for 5 days. Ripening lasts from 3 (semi-soft) to 15 months (hard) during which the cheese is stored in the dark on wooden tables under controlled moisture and temperature conditions. The final Carmasciano is gently piquant, has a strong smell, and a soft and elastic paste, which hardens in long-ripened cheeses. In the seasoned product, the rind is clear yellow with brown shadings. Semi-seasoned cheese is eaten with broad beans and chestnut honey as table cheese, while the ripened cheese is grated (Capobianco et al. 2005). The low milk temperatures used during cheese processing allows the typical milk microflora to survive and to play an important role in the development of its sensory characteristics.

During cheese ripening, the presence of microbial amino acid decarboxylase activity and free amino acids can cause the production of undesirable compounds, such as BA. Monoamine oxidase-inhibiting drugs and/or alcohol and gastrointestinal diseases can increase toxic BA effects and cause health risks in sensible consumers. Research on food safety characteristics of Carmasciano is rather limited. In particular, data on biological and vasoactive amine content are not available. The aim of this study was to investigate the formation of HIS, TYR, and other BAs during ripening.

\section{Materials and methods}

In the period from October to March 2008 nine samples of Carmasciano were randomly selected from the ripening room on the production day and subsequently after 1736,47 , $82,117,147,175$, and 201 days of ripening. On each sampling day one piece of cheese was transported under refrigeration to the laboratories of the Food Inspection Section where it was analyzed. Cheese (10 g), including rind and paste, was homogenized and determination of the amines HIS, TYR, PTR, SPD, SPR, and cadaverine (CAD) was carried out by acid extraction, dansyl chloride derivatization, and HPLC/ Fp analysis (Porta et al. 1983).

\section{Results}

Six amines were found during the ripening of Carmasciano. TYR levels were $473.5 \mathrm{mg} / \mathrm{kg}$ at the beginning, $69.9 \mathrm{mg} / \mathrm{kg}$ on day 82 , and $136.41 \mathrm{mg} / \mathrm{kg}$ on day 201 . HIS content was $137.81 \mathrm{mg} / \mathrm{kg}$ initially, $45.6 \mathrm{mg} / \mathrm{kg}$ on day 82 , and $65.5 \mathrm{mg} / \mathrm{kg}$ on day 201 (Fig 1). The amines PTR, CAD, SPD, and SPR showed an increasing trend ranging from 0.7 to $348.4 \mathrm{mg} / \mathrm{kg}$ (Fig. 2). 


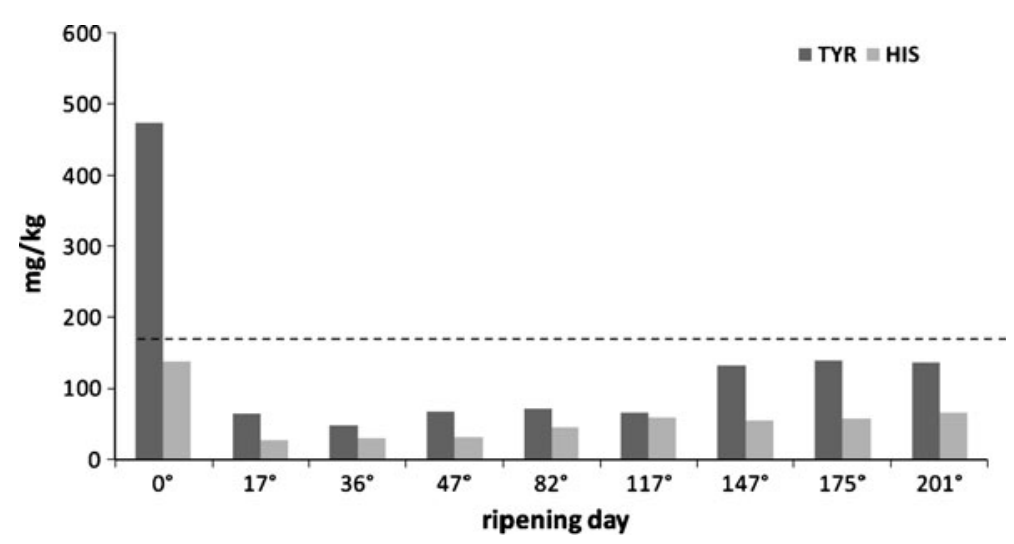

Fig. 1 Vasoactive Tyramine and Histamine levels during ripening

\section{Discussion}

Regulation EC/2073/05 established microbiological limits in fish for only HIS, specifically $100-200 \mathrm{mg} / \mathrm{kg}$ in fresh products and $200-400 \mathrm{mg} / \mathrm{kg}$ in fish products obtained by enzymatic maturation in brine. At the moment, no legal limit is established for TYR. However, TYR has a high toxicity threshold $(400 \mathrm{mg} / \mathrm{kg})$ in the presence of effective amine-detoxifying enzymes (monoamine oxidase or MAO). Other amines do not show biological activity, but can increase the toxicity of vasoactive amines if significant levels are present in foods. In fact, SPR and SPD, administered per os under the experimental conditions showed higher toxicity (NOAEL $200 \mathrm{ppm}$ and $1000 \mathrm{ppm}$, respectively) than CAD and PTR (2000 ppm) (Til et al. 1996).

The potential formation of BA during production and ripening of fermented products deserves careful attention, as confirmed by the project Biogenic Amines in Traditional Food Fermentations in Regional Europe, 7th Framework. The aims of that study were to identify the decarboxylase-positive microorganisms and to study the conditions capable of reducing BA levels during processing of fermented drinks and foods.

The Carmasciano amine profile showed the typical changes occurring during ripening and confirmed that BA quality and levels may be very variable and related to multiple

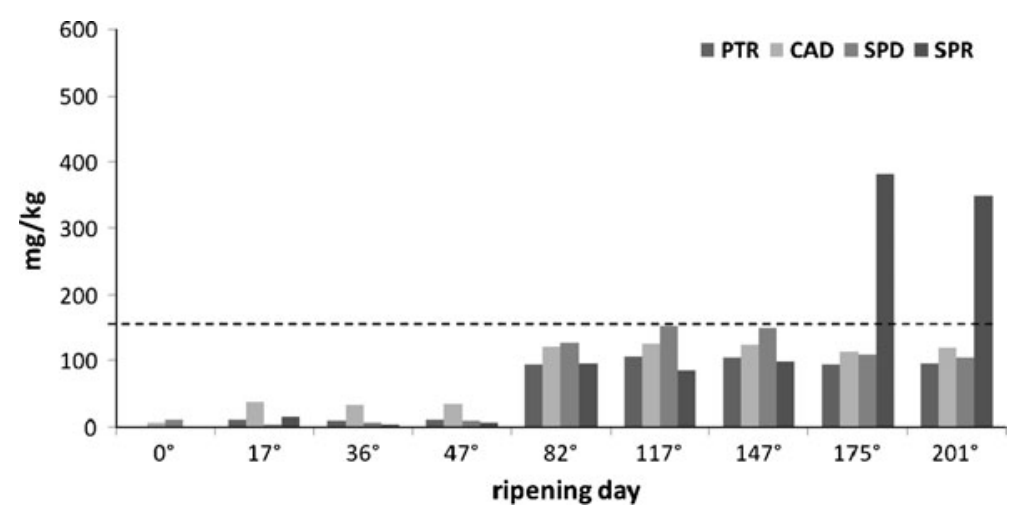

Fig. 2 Levels of biogenic amines during ripening 
factors (Martuscelli et al. 2005). Starter cultures are not used in Carmasciano technology so that the natural milk microorganisms play a significant role in cheese production. Regulation EC/853/04, in order to protect traditional food productions, allows flexibility during production and ripening, provided that safety is not compromised. Gradual decreases in water activity (Aw), salt concentration, and competitive lactic bacteria can guarantee the respect of food safety criteria.

In the analyzed cheese samples the endogenous microflora proteolysis, the cheese production temperature $\left(45^{\circ} \mathrm{C}\right)$, and the low salt percentage (around $2.7 \%$ ) caused the BA formation. After three months of ripening PTR, CAD, SPD, and SPR showed concentrations higher than HIS or TYR. SPR was the amine that showed the highest levels after seven months of ripening $(348.4 \mathrm{mg} / \mathrm{kg})$. On the whole, the BA profile of Carmasciano demonstrated that the vasoactive BA levels were not significantly higher despite the traditional technology, and were always below the limits established for other kinds of foods. However, data relating to raw material and the increasing trend of some BAs stresses the need for controlling the indigenous bacterial population responsible for amine production, implementing good manufacturing practices, and adequate staff training.

\section{References}

Capobianco F, Pacifico S, Panfili G, Salimei E, Coppola R (2005) Aspetti tecnologici e microbiologici del Pecorino Carmasciano. Industrie Alimentari XLIV:150-155

Martuscelli M, Gardini F, Torriani S, Mastrocola D, Serio A, Chaves-Lòpez C, Schirone M, Suzzi G (2005) Production of biogenic amines during ripening of Pecorino Abruzzese cheese. Intl Dairy J 15:571-578

Porta R, Schatz RA, Tatters SB, Sellinger OZ (1983) The biosynthesis of polyamines in mouse brain: effects of methionine sulfoximine and adenosylhomocysteine. J Neurochem 40:836

Stratton SS, Hutkins RW (1991) Biogenic amines in cheese and others fermented foods: A rewiew. J Food Protection 54:460-470

Til HP, Falke HE, Prinsen MK, Willems MI (1996) Acute and subacute toxicity of tyramine, spermidine, spermine, putrescine and cadaverine in rats. Food Chem Toxicol 35:337-348

Valsamaki K, Michaelidou A (2000) Biogenic amine production in Feta cheese. Food Chem 71:259-266 